Grapes, Grain and Grey Cats: Binary Dynamics in Dutch Higher Education Author(s): Leo C. J. Goedegebuure

Source: European Journal of Education, Vol. 27, No. 1/2 (1992), pp. 57-68

Published by: Wiley

Stable URL: https://www.jstor.org/stable/1502663

Accessed: 03-12-2019 15:01 UTC

JSTOR is a not-for-profit service that helps scholars, researchers, and students discover, use, and build upon a wide range of content in a trusted digital archive. We use information technology and tools to increase productivity and facilitate new forms of scholarship. For more information about JSTOR, please contact support@jstor.org.

Your use of the JSTOR archive indicates your acceptance of the Terms \& Conditions of Use, available at https://about.jstor.org/terms

Wiley is collaborating with JSTOR to digitize, preserve and extend access to European Journal of Education 


\section{Grapes, Grain and Grey Cats: binary dynamics in Dutch higher education}

\section{LEO C. J. GOEDEGEBUURE}

It appears that increasing vocationalisation in higher education is an issue in many countries. Economic considerations have been prominent among the outside pressures being put on higher education in recent years, with governments in a number of countries actively involved in creating structural conditions that are supposed to resemble markets. Competition for both students and financial resources is the order of the day (e.g. Neave, 1990), while higher education as such is perceived more and more as an instrument to bring about economic growth in both nation states and supranational entities like the European Community (Task Force, 1991). Perhaps Australia is the most extreme case in this respect, with the concept of the "clever country" (Higher Education Council, 1991). But in many other countries the same instrumentalist view of higher education has become part and parcel of government policy in an attempt either to revitalise ailing economies-the United Kingdom is an obvious example in this respect-or actually to create market economies, as is happening in Central and Eastern Europe (e.g. Cerych, 1990; Hendrichova, 1991). Notwithstanding the fact that market-like elements are playing an increasing role, European higher education systems by and large are public systems in which governments are the main providers of resources, and these public systems still conform to the golden rule. As governments are prepared to back their increasingly instrumentalist orientation on higher education with cash through various priority schemes and forms of selective funding, this seems to imply that the system is becoming more vocationally oriented.

Considered in the above context, vocationalism appears to suggest an emphasis on economic relevance and readily applicable skills and knowledge. There is no denying that these are indeed the essential ingredients of the vocational concept. However, there also is no denying that over the years the concept has acquired a somewhat negative image. As Silver \& Brennan state:

The term vocational acquired the submeaning of specific low status and related to the servile operations of industrial, commercial Britain. It also became associated with narrowness and practicality, and came as a result to be contrasted with breadth and academic. These were not semantic distinctions, but reflections of attempts to define social hierarchies: the academic ranks above the practical (...); knowing (science) ranks above doing (technology); higher honour is paid to the academic than to the technical (...). Liberal comes to denote general or unspecific-and therefore free-ranging and superior to the vocationally and directly 'useful'. (1988, p. 27)

The distinction between liberal and vocational, and the associated value assumptions, has a strong parallel in most established binary systems. Even though binary 
systems as a rule are founded on the 'equal but different' philosophy, in reality there is often a distinct hierarchical relationship between the two sectors, with the universities at the top and the non-university institutions classed as the 'less noble' type (OECD, 1974) somewhere below. It has been argued that binary systems display a tendency towards integration through emulation processes in which those institutions located at the bottom of the status ladder ape those at the top (Neave, 1983). And there is little doubt that the relentless pressure from a number of institutions located in the nonuniversity sector to be granted both university status and the associated financial benefits has led to the demise of the Australian and British binary systems (Kogan, 1991; Meek, 1991). A popular metaphor in this respect is the notion of academic drift, implying not so much a process of vocationalisation as one of academisation within the system. As such, one could assume that two-tier systems structured on the basis of the equal but different principle will show signs of increasing academisation. A contrary trend is indicated by the efforts of governments to steer systems in a more economically relevant direction, with the implicit assumption of increased vocationalism.

Within the framework of these two assumptions, the Dutch case is interesting as the higher education system is binary and there are also indications that the Dutch government is indeed adopting a more instrumental perspective on higher education, albeit not as strong as in some other countries. To what extent this leads to changes and perhaps contradictions in the notion and development of higher education will be explored in the next sections. In order to clarify the particular nature of Dutch higher education, we begin with a brief description of the rise of the system, with particular emphasis on the non-university sector. Second, the possible processes of 'vocationalisation' and 'academisation' will be tackled from an empirical point of view. By exploring the developments with respect to a number of indicators, an attempt is made to provide a provisional answer to the question of whether vocationalisation and/or academisation predominates within the Dutch system.

\section{The Rise of the Dutch Binary System}

Formally speaking, the Dutch binary system is of recent date, but its constituent parts have a respectable history. The first university was founded in Leiden in 1575 as a reward for the citizens' persistence in fighting the Spaniards during the 80-year war. The establishment of the University of Leiden was followed by others in subsequent years; e.g. the universities of Groningen (1614), Amsterdam (1632) and Utrecht (1634). More recently other universities were founded, partly as an explicit government economic policy to promote activity in some disadvantaged regions (the University of Twente, 1961, and the University of Limburg, 1976). In all, the university sector at present consists of 13 institutions.

The non-university sector, known as the HBO sector (Higher Vocational Education), can also be traced back quite far, but it developed under very different circumstances. It is generally agreed that the oldest institution still existing is the Royal Academy of Fine Arts, which was founded in 1682 in The Hague, but most of the oldest institutions have their roots in the 19th century. Until 1818 vocational education was concentrated in the guilds. The abolition of these institutions brought the need to create a new institutional infrastructure for high level vocational education. The first attempts to incorporate vocational training in existing evening schools did not suffice, as these initiatives were of limited scope and very diverse quality. The need for a well-qualified industrial labour force resulted in the establishment of the Royal 
Academy in Delft in 1842, specialising in mining, shipbuilding and hydraulics [1]. This was followed by the creation of technical schools in 1861 and an expansion of the existing trade (evening) schools. Noteworthy in this development is the reluctance already present in those days to create a legal framework for vocational education, despite the fact that it was considered to be important-a trait that continued far into the 20 th century.

The first legal framework was provided by the 1919 Domestic Science and Technical Education Act, differentiating among other things between primary and secondary domestic and technical education. After the Second World War vocational education expanded further, and with the creation of a new type of education between primary and secondary, secondary domestic and technical education was upgraded to 'higher'. In 1968 it was renamed 'higher vocational education' with the passing through parliament of the Secondary Education Act (SEA), which codified all forms of education between primary school and university. One of the characteristics of the SEA, and the way in which the Ministry of Education and Science used it, was a detailed regulation of institutional affairs, thus severely restricting the subsequent development of the HBO sector-a sector that, inter alia, was extremely diverse and fragmented in those days. As one observer noted, the only unity within the sector was that "all these dissimilar units... are under one denominator in the SEA" (Zeijan, 1974, p. 15).

The main features of the period from the late 1960 s to the early 1980 s were substantial growth and much discussion about the system. Student numbers rose rapidly, creating the beginnings of budgetary pressures that were to dominate the 1980s. In line with developments in other countries, the non-university sector was considered ideal to take care of this increasing student body, as (i) it was considerably cheaper than the university sector, and 'education on the cheap' even then was considered an asset; (ii) it catered for part-time education; and (iii) it provided the kind of orientation perceived as beneficial to the growth of the Dutch economy. Expansion of the HBO sector, however, also gave rise to discussions about both the internal structure of the sector and its relationship with the university sector. This resulted in a multitude of green and white papers with different scenarios such as the draft bill Development Higher Education (1973), Higher Education in the Future (1975), the Contour Paper (1975), and Higher Education for the Many (1978). Apart from the interesting rituals, diverging political views, and rhetoric that accompanied these initiatives, the actual results were meagre. The non-university sector was praised for its values and efforts, but little was done to take it out of the developmental straitjacket of the 1968 SEA. It took until 1983 before decisive action was taken by the Dutch government.

In 1983 the then minister for Education and Science, Wim Deetman, published the white paper Scale-enlargement, Task-reallocation and Concentration (STC), proposing a major restructuring of the $\mathrm{HBO}$ sector that has had far-reaching consequences for the present structure and functioning of the Dutch higher education system. The main objectives of the STC restructuring were threefold:

(a) a considerable increase in size through mergers of institutions;

(b) an increase in institutional autonomy with regard to the use of resources, personnel policy and the structuring of the educational processes;

(c) an increase in institutional efficiency through economies of scope.

The minister envisaged that the result of the implementation of the STC policy would 


\section{0}

be a limited number of multi-purpose, medium-sized institutions with considerable autonomy. The outcomes of the merger processes, however, surpassed all expectations: by July 1987 the original 350 institutions had merged into 85 mostly large to very large, multi-purpose institutions. Some of them turned out to be larger than most of the existing universities. Thus, in terms of structure, the institutional landscape of Dutch higher education had changed dramatically [2]. In terms of function, increased autonomy was to be attained on the one hand through the implementation of the new governmental steering philosophy (Maassen \& Van Vught, 1988; Ruiter \& Van Vught, 1990), and on the other hand through the framework provided by the new HBO Act (1986) that at last took HBO out of the realm of secondary education and placed it in higher education, thereby formalising the already existing binary structure.

One of the most striking features of the structural changes that have confronted the HBO institutions is that change still continues. Mergers are still taking place, clearly aiming for strategic positioning and market dominance. Since already large institutions are merging, the results sometimes are gigantic institutions by Dutch standards; a recent merger in the southern part of the country resulted in an institution with over 30,000 students. With their new-found freedom for action, course expansion has been substantial. In the period 1988-1991 over a thousand applications have been filed with the Ministry of Education and Science to start new study programmes, some 500 of which were full-time courses. For more than 360 programmes, government permission has already been granted (Box, 1991), implying a major increase in the course offerings of the $\mathrm{HBO}$ institutions.

These institutional activities have been accompanied by a surge in collective HBO action to improve the status of the sector vis-à-vis the universities. Following the adage that parity of esteem should imply parity of funding and parity of developmental possibilities-the Dutch binary system is still based on the equal but different philosophy-the HBO Council, as the intermediate organisation of the sector, has launched a campaign to incorporate research as one of the legitimate tasks of HBO in the higher education framework law that is about to be discussed in parliament, to shift funding from the university to the non-university sector, to discuss fully the present and future structure of the Dutch binary system, in short, to put the HBO sector at least on a par with the universities. These activities will be discussed in the next sections.

In an attempt to clarify the nature of the $\mathrm{HBO}$ sector, Table I provides a broad overview of similarities and differences between $\mathrm{HBO}$ and university course offerings. In examining this overview, it should be kept in mind that unlike, for example, the British polytechnics, HBO institutions do not offer the same degrees as do universities in terms of the regular curriculum. The first and terminal HBO qualification is the bachelor's degree, while universities award the master's as their first degree and can also award doctorates. However, in terms of their disciplinary offerings, HBO institutions are far more comparable to the British polytechnics than, for example, to the German Fachhochschulen which offer a distinctly narrower range of studies. Table I is arranged according to the division into subject areas used by the Dutch government. This is admittedly an aggregated level, but a more detailed scheme would be too complicated for clarity.

\section{Vocationalisation in Dutch Higher Education?}

With increasing regularity, claims are being made in the Dutch higher education press 
TABLE I. Types of education by type of institution and field

\begin{tabular}{|c|c|c|}
\hline & Non-university & University \\
\hline Agriculture & $\begin{array}{l}\text { Business administration, forestry, } \\
\text { engineering, food technology, Dutch } \\
\text { agriculture, tropical agriculture, } \\
\text { horticulture, cattle breeding }\end{array}$ & $\begin{array}{l}\text { Biology, forestry, domestic and } \\
\text { consumer sciences, engineering, food } \\
\text { technology, molecular sciences, rural } \\
\text { development, horticulture, plant } \\
\text { improvement }\end{array}$ \\
\hline Engineering & $\begin{array}{l}\text { Laboratory education, maritime } \\
\text { education, business studies, building, } \\
\text { electrical engineering, informatics, } \\
\text { engineering physics, civil engineering, } \\
\text { mechanical engineering }\end{array}$ & $\begin{array}{l}\text { Civil engineering, building, mechanical } \\
\text { engineering, electrical engineering, } \\
\text { chemical engineering, engineering } \\
\text { physics, business studies, mining, } \\
\text { geodesy }\end{array}$ \\
\hline Healthcare & $\begin{array}{l}\text { Dietetics, nursing, occupational } \\
\text { therapy, physiotherapy, speech therapy, } \\
\text { radiation therapy, nursing education }\end{array}$ & $\begin{array}{l}\text { Medicine, dentistry, veterinary science, } \\
\text { community healthcare }\end{array}$ \\
\hline Economics & $\begin{array}{l}\text { Accountancy, business economics, } \\
\text { commercial economics, tourism, } \\
\text { translation, applied home economics, } \\
\text { hotel management, library, } \\
\text { documentation and information, } \\
\text { journalism }\end{array}$ & $\begin{array}{l}\text { Economics, econometrics, information } \\
\text { management, business administration, } \\
\text { short course [Japanese studies, East } \\
\text { European studies, ergonomics] }\end{array}$ \\
\hline $\begin{array}{l}\text { Behaviour and } \\
\text { society }\end{array}$ & $\begin{array}{l}\text { Social work, welfare work, youth } \\
\text { welfare work, labour market and } \\
\text { personnel (policy), creative therapy }\end{array}$ & $\begin{array}{l}\text { Psychology, sociology, political science, } \\
\text { geography, public administration, } \\
\text { healthcare, educational science }\end{array}$ \\
\hline $\begin{array}{l}\text { Language and } \\
\text { culture }\end{array}$ & $\begin{array}{l}\text { Visual arts, performing arts, } \\
\text { museology, teacher training }\end{array}$ & $\begin{array}{l}\text { Theology, philosophy, languages, (art) } \\
\text { history, theatre studies }\end{array}$ \\
\hline Education & $\begin{array}{l}\text { Teacher training (primary education), } \\
\text { teacher training (secondary education) }\end{array}$ & \\
\hline Science & & $\begin{array}{l}\text { Mathematics, informatics, physics, } \\
\text { astronomy, chemistry, pharmacy, } \\
\text { biology, earth sciences }\end{array}$ \\
\hline Law & & $\begin{array}{l}\text { Law (public, private, international, } \\
\text { etc.) }\end{array}$ \\
\hline
\end{tabular}

and in political statements that the lines between university and non-university higher education are becoming more and more blurred. In the explanatory memorandum of the draft framework law on Higher Education and Science Research it is stated that universities and HBO institutions each have their own identity: university education is seen as closely connected with scientific research, while HBO education is typified by its strong interaction with the professional fields. Supporters of the $\mathrm{HBO}$ sector argue, however, that universities are trespassing on their territory by offering predominantly vocational programmes like journalism, European studies, etc. The university community, on the other hand, claims that $\mathrm{HBO}$ institutions are becoming more and more academic in their content and attitude, and often points to the growing research orientation within the HBO sector. Employers broadly speaking support both claims, with differing emphases depending on the state of the stock exchange. In general the above statements are made without any empirical substance. But if one adheres to the notion of 'no smoke without fire', they can be seen as an expression of a certain unease with the present split in the Dutch higher education system. In this section some 
indicators are used in an attempt to shed more light on this controversial issue. For a start, some developments on the macro level of the system are highlighted.

TABLE II. Enrolments in Dutch higher education

\begin{tabular}{|c|c|c|c|c|c|c|c|c|}
\hline & \multicolumn{2}{|c|}{1975} & \multicolumn{2}{|c|}{1980} & \multicolumn{2}{|c|}{1985} & \multicolumn{2}{|c|}{1990} \\
\hline & No. & $\begin{array}{c}\text { Per- } \\
\text { centage }\end{array}$ & No. & $\begin{array}{c}\text { Per- } \\
\text { centage }\end{array}$ & No. & $\begin{array}{c}\text { Per- } \\
\text { centage }\end{array}$ & No. & $\begin{array}{c}\text { Per- } \\
\text { centage }\end{array}$ \\
\hline \multicolumn{9}{|c|}{ 1st year enrolments } \\
\hline HBO & 34,200 & 60 & 39,100 & 60 & 42,200 & 59 & 52,800 & 58 \\
\hline University & 22,700 & 40 & 26,800 & 40 & 29,500 & 41 & 37,800 & 42 \\
\hline \multicolumn{9}{|c|}{ Overall enrolments } \\
\hline HBO & 104,300 & 47 & 128,900 & 48 & 146,100 & 49 & 191,900 & 54 \\
\hline University & 116,600 & 53 & 139,300 & 52 & 154,500 & 51 & 160,400 & 46 \\
\hline
\end{tabular}

Source: Feiten en Cijfers (1991).

If we look at developments in terms of student numbers, it is clear from Table II that the $\mathrm{HBO}$ sector is taking care of the majority of new entrants into higher education. As the increase in the demand for higher education has been met predominantly in the HBO sector-enrolments increased by $84 \%$ compared with a $38 \%$ increase in the university sector-HBO has also become the largest sector in higher education. However, this growing popularity of HBO education should not be identified automatically with an increasing demand for vocational education as such. First of all, it should be recognised that substantial shifts in the backgrounds of entering students have occurred that may here lead effects on the Curriculum Contents of HBO courses. As can be seen from Fig. 1, the relative proportion of general upper secondary (HAVO) graduates - the traditional background for $\mathrm{HBO}$ - has declined sharply (from $46 \%$ to $29 \%$ ), while enrolments by vocational upper secondary (MBO) graduates have increased very strongly (from $9 \%$ to $25 \%$ ). Within the Dutch system, MBO is considered a terminal degree, but apparently students hold a different opinion. At the same time, HAVO graduates of all types enrolling in higher education are increasingly facing problems in successfully completing their first year-a situation that is viewed with concern within the $\mathrm{HBO}$ sector, and is thought to be the result of the poor quality of the HAVO graduates. Whether these graduates actually are of lower quality than they used to be or whether HBO programmes have become more difficult over the years, is a question that has been carefully avoided so far. In a way, these shifts in enrolment patterns and success rates can be seen as an indication that something at least has changed in the HBO curriculum. To what extent it is enough evidence to support the claim of academisation is an open question, especially as other tendencies exist as well.

An HBO degree, like an MBO degree, is considered to be a terminal qualification. Nevertheless, an increasing proportion of HBO graduates supplement their HBO studies with a university course to obtain a master's degree. Preliminary data from a research project on this phenomenon suggests that the number of $\mathrm{HBO}$ students who follow this educational route has more than doubled since 1983; in 1990 some 5000 of the roughly 37,000 new enrolments in the university sector were former $\mathrm{HBO}$ graduates, which is $13.2 \%$ (Vossensteijn, 1992). If we assume that this is not an expression of irrational behaviour, it implies that, from a student's point of view, there 


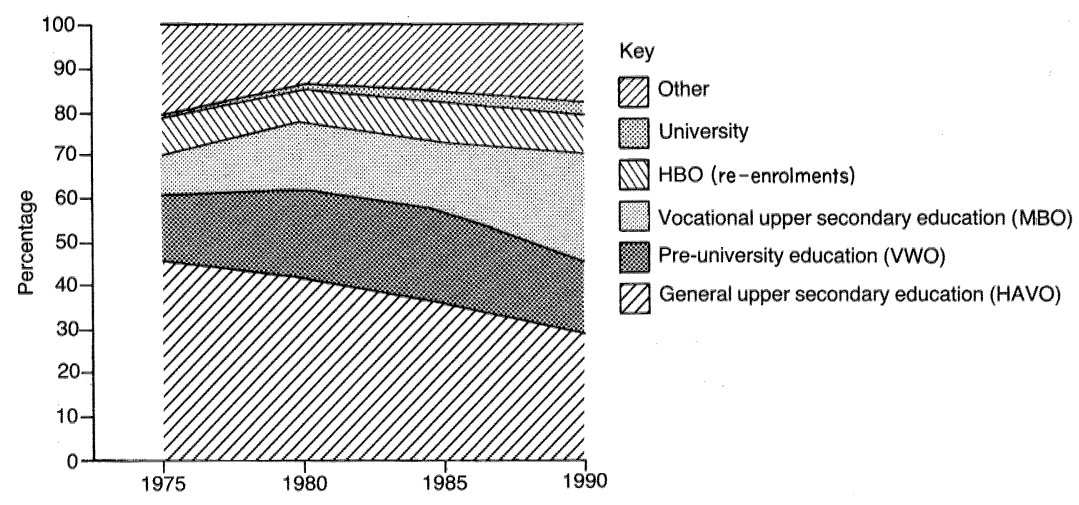

FIG. 1. Educational background of students entering HBO.

are still differences between $\mathrm{HBO}$ and university degrees and that it is worthwhile spending a few extra years in a university to obtain an additional degree. Possibly this is a reflection of the different value attributed to these qualifications by the labour market: university graduates in general are paid substantially larger salaries than HBO graduates, but there are also indications that these differences are diminishing (Nijeboer, 1990).

This leaves us with a rather mixed picture regarding the possibility of academic drift. There definitely are changes in enrolments and quite likely in curricula as well, but, certainly from a macro point of view, the evidence is far from conclusive. On the other hand, it should also be noted that $\mathrm{HBO}$ does follow some of the patterns that have been considered indicative of the occurrence of academic drift (Moses, 1991): research is becoming more important, even though its volume is negligible compared to the universities' activities in this respect; and enrolment patterns are shifting. No hard evidence is as yet available regarding the composition of staff, so little can be said on a possible growing convergence of the characteristics of teachers in universities and $\mathrm{HBO}$ institutions. Last but not least, some institutions now offer the possibility of obtaining a master's degree through association with British polytechnics, although this option is usually located in the realm of 'postgraduate studies'. The above trends will not therefore automatically result in an academisation of the $\mathrm{HBO}$ sector; an explicit and substantiated case of academic drift does not exist. What it does indicate, however, is that there are a number of areas in the HBO sector in which quite fundamental changes are taking place-changes that might have a profound effect on the relationship with the university sector. This said, it should also be recognised that the university sector is not a static entity, but is also open to change, albeit in a more incremental manner.

Especially over the last ten years, the university sector in the Netherlands has been under constant pressure to rationalise, innovate and adapt to changing external circumstances. There is little question that the universities have changed during this period. Productivity as measured in the numbers of publications, $\mathrm{PhDs}$, etc., has increased substantially (Kaiser et al., 1989); curricular changes have been implemented to adapt to larger numbers of students; and in general a more business-like manner has come over these institutions. Within the framework of the 'adaptive institution' that the Ministry of Education and parliament have continuously emphasised in their policy approach towards the universities, knowledge transfer centres, business and science 
parks, contract education and research have developed. As demands from society-atlarge in general tend to be of a rather applied nature, it should be no surprise that the activities of the university sector have been expanded into what could be termed the 'vocational realm'. In this respect, objections from HBO proponents are understandable, but objections of this kind from government and parliament could be seen as somewhat naive. If funds are becoming scarce, and possibilities exist to supplement core funding with external sources, it is very likely that this will involve work of an applied nature. If one looks at the statistics on the distribution of personnel in terms of research areas, over the period 1980-1988 staff paid out of the universities' core funding, i.e. enrolment-related funding, increased by some $25 \%$. For staff employed through research agencies' grants (the so-called second-flow of funds), the increase was $85 \%$. But for staff employed on the basis of contract funds, the increase has been $243 \%$. From this it can be concluded that the university sector has substantially expanded its activities towards the market sector, and that increases in academic staff employed at universities are first and foremost funded through contact activities.

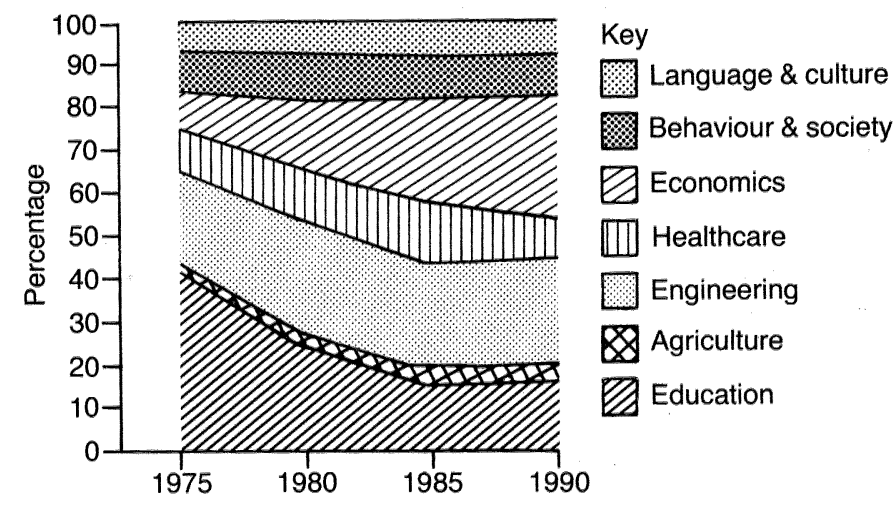

FIG. 2. Enrolments in the HBO sector by field of study.

However, in terms of traditional university activities-teaching and fundamental research-changes at the macro level are far less striking. For quite a number of years, the Dutch government has been actively encouraging (female) students to enrol in the technical sciences as part of its instrumentalist market-oriented and emancipatory higher education policy. Universities have supported these policies, but the effects have been minimal. As can be seen from Figs. 2 and 3, university enrolment patterns have changed very little over the last 15 years, with the possible exception of the market-oriented sector. HBO enrolment patterns have changed quite dramatically, with a huge decline in enrolments in the education sector and a very large increase in the market-oriented sector. Changes in engineering and science enrolments have been very limited, and recent figures indicate that although female participation in higher education is rising quickly, female students do not enrol in the hard sciences, but opt for the traditional liberal studies like psychology, sociology and languages. In this respect, the emphasis within universities on the dominant fields of study has not changed all that much over the years, and the same can be said for the emphasis in research. As is indicated in Table III, research activities based on the core funding (first-flow of funds) hardly changed, agency-funded research (second-flow of funds) shows a slight shift from science to engineering and a general increase for the 'soft 
fields' behaviour and science and language and culture. Contract-based research shows a slight shift from health and behaviour and science towards science and engineering. But overall, these shifts hardly can be considered as fundamental changes in terms of curricular and research emphasis within the university sector.

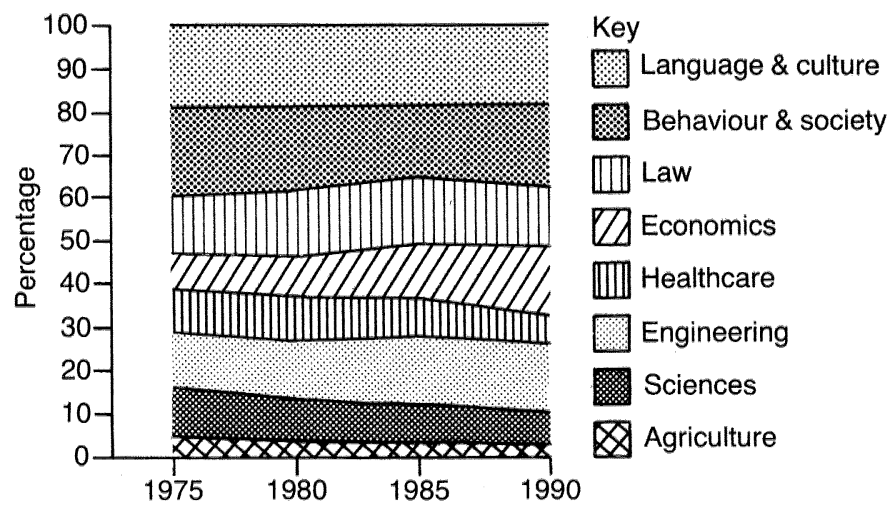

FIG. 3. University enrolments by field of study.

TABLE III. University research capacity (fte) by field and flow of funds (\%)

\begin{tabular}{|c|c|c|c|c|c|c|c|c|c|}
\hline \multirow[b]{2}{*}{ Flow of funds } & \multicolumn{3}{|c|}{ First } & \multicolumn{3}{|c|}{ Second } & \multicolumn{3}{|c|}{ Third } \\
\hline & 1980 & 1985 & 1988 & 1980 & 1985 & 1988 & 1980 & 1985 & 1988 \\
\hline Agriculture & 4 & 5 & 5 & 2 & 4 & 3 & 5 & 6 & 7 \\
\hline Science & 22 & 21 & 20 & 58 & 42 & 42 & 11 & 12 & 16 \\
\hline Engineering & 16 & 18 & 20 & 8 & 16 & 15 & 12 & 12 & 15 \\
\hline Health & 20 & 20 & 19 & 16 & 14 & 13 & 37 & 35 & 32 \\
\hline Economics & 4 & 4 & 5 & - & 1 & 2 & 2 & 3 & 2 \\
\hline Law & 5 & 6 & 7 & - & 1 & 2 & 3 & 1 & 2 \\
\hline Behaviour and society & 15 & 14 & 14 & 8 & 14 & 11 & 28 & 28 & 23 \\
\hline Law and culture & 13 & 12 & 11 & 7 & 9 & 12 & 2 & 3 & 4 \\
\hline
\end{tabular}

Source: Feiten en Cijfers (1991, tables 205, 207).

At the micro level, curricular changes especially are more noteworthy. As the battle for students is taking place in the Netherlands as elsewhere, universities have increased their programme offerings in an attempt to attract more students. These changes are not so much in the form of offering completely new degrees, but far more in offering increased options for specialisation after obtaining the propaedeutic exam, the socalled 'upper structure' programmes. It is in the creation of these differentiations that the dividing lines with higher vocational education are supposed to be becoming more blurred. There is no denying that, general speaking, these studies are of a more applied nature. The question is whether they are basically different or not. Comparability in name cannot be considered ample evidence of overlap between the programmes, and no hard empirical evidence exists to substantiate either the one or the other. In relation to this question, it is worth noting that a recent study on curricular developments in the humanities and the social sciences indicated that various attempts have been made 
to ensure greater vocational and social relevance in these courses, and that attempts have been made to move away from traditional disciplinary models to more convergent patterns. At the same time it is stressed that the most likely important characteristics of graduates are not those directly related to the curriculum, but the extra-curricular, academic abilities and personal qualities (Weert, 1991). These elements still take up an important part of higher education in the university sector, and as such differentiate this sector from the more narrowly vocational $\mathrm{HBO}$ sector.

\section{Conclusions}

In the most recent policy statement of the Dutch government on higher education, it is argued that because of the knowledge-intensive nature of the present and future (European) society, the importance of the technical and natural sciences in this, and the fact that Dutch students appear to be slow in following these type of courses, effort should be put into the promotion of technical and natural sciences studies, and enrolments in studies with deteriorating employment prospects should be discouraged (HOOP, 1992). A similar position had been taken earlier by both the Social Economic Advisory Council (SER) and the Ministry of Economic Affairs. From a policy perspective, it appears that higher education is seen as an instrument of economic policy. As has been indicated in the previous section, however, higher education does not fully agree with these calls for relevance. In other words, it is clear that student choices are difficult to direct, as the strong governmental emphasis on science and technology is not reflected in the enrolment patterns. At the sector level, far-reaching changes have been noted with respect to the non-university sector, in particular in terms of enrolments and structural features. It has also been demonstrated that the university sector has changed over the last ten years and has become more adaptive and market-oriented.

On the basis of these findings, however, it cannot be concluded that Dutch higher education has undergone a straightforward vocational shift. Empirical data for such a claim should come from the programme level and are not available. What has become clear, on the other hand, is the emergence of new patterns of relationships between the university and the non-university sector in the Netherlands. The non-university sector is quite overtly attempting to take its place alongside, and at the same level as, the university sector. The university sector is trying to protect its own position at the top of the higher education hierarchy. The tensions and dynamics that are the result of this interplay of contrasting forces is changing the face of Dutch higher education. The governmental position at present is that one should not mix grapes and grain; university and non-university higher education should be different in outlook and emphasis; are defined as different in policy statements and law; and therefore are different and should remain so. In the political arena especially, this difference is being challenged and suggestions are being made that the line between the two tiers is becoming blurred. The extent to which this statement can be supported is questionable. Indeed, all cats look grey in the dark, but in the daylight they can well be very different. I would suggest this is the case as well with the universities and the HBO institutions in the Netherlands. There is no denying that in certain areas there is overlap and duplication between the sectors. But at the moment they are still fundamentally different in their approach to higher education. Whether they will remain so is an entirely different question-a question that very much depends on the way in which higher education policy will be formulated at the governmental level. If 
the equality of the two sectors is achieved only in terms of semantics without material benefits for the non-university sector, it appears likely that processes of academic drift will indeed develop in order to attain actual parity. If, on the other hand, a viable way is found to identify the different roles of the two sectors and combine this with full equality, the binary system might flourish.

At present, Dutch policy has not reached this 'viable option'. By continuously referring to the old dichotomies of teaching and research, and fundamental versus applied research, it is unlikely that a fruitful distinction will be established as there are too many value connotations attached to these concepts. If a distinction is to remain, it should be a functional one, relating to the characteristics of the two sectors in terms of the principal activities undertaken. That such a conception is not an easy one to develop will hopefully also have become clear by looking at the characteristics of the two sectors presented before. In any case it should be realised that any formal differentiation between the two sectors has its limitations, as higher education systems and the sectors within them are not static entities but dynamic elements within the larger system in which they are located. They are continuously changing through their relationships and exchanges with other parts of the system. Seen in this perspective, a binary system might be nothing more than one phase in a continuous range of equilibria, making the statement that one needs a binary system in order to destroy it, more than mere logic.

\section{NOTES}

[1] After becoming a 'Polytechnic School' in the 1860s, the institution was promoted to 'Technische Hogeschool' in 1904-the Dutch term for technological university (Schippers, 1989). It can therefore be considered a good example of 'academic drift avant la lettre'.

[2] For a more elaborate discussion of the process and outcomes of the merger operation, see Goedegebuure $(1989,1992)$.

\section{REFERENCES}

Box, J.M.F. (1991) Macro-doelmatigheid en het lemmingen-effect, Tijdschrift voor Hoger Onderwijs, 9(4), pp. 219-229.

CERYCH, L. (1990) Renewal of central European higher education: issues and challenges, European fournal of Education, 25(4), pp. 351-360.

GoEDEGEBUURE, L.C.J. (1989) Institutional mergers and system change, in: P. A. M. MAassen \& F. A. VAN Vught (Eds) Dutch Higher Education in Transition (Culemborg, Lemma).

GoEDEGEBUURE, L.C.J. (1992) Mergers in Higher Education: a comparative perspective (Utrecht, Lemma).

Hendrichova, J. (1991) Higher education in Czechoslovakia: some problems of the transition period, Higher Education in Europe, 16(3), pp. 46-56.

Higher EducATION COUNCIL (1991) Higher Education: the challenges ahead (Canberra, AGPS).

HOOP (MINISTERIE VAN ONDERWIJS EN WETENSCHAPPEN) (1991) Ontwerp Hoger Onderwijs en Onderzoek Plan 1992 (The Hague, SDU).

Kaiser, F., Koelman, J.B.J. \& Van Vught, F.A. (1989) Doelmatigheid in het 
wetenschapelijk onderwijs en onderzoek, Economisch Statistische Berichten, 74(3710), pp. 552-555.

KogaN, M. (1991) Binary systems in higher education: the British experience, paper presented at the Special Conference on 25 Years After the Martin Report, University of New England, Armidale, Australia.

MAASSEN, P.A.M. \& VAN Vught, F.A. (1988) An intriguing Janus-head, the two faces of the new governmental strategy for higher education in the Netherlands, European fournal of Education, 23(2/3), pp. 65-77.

MAASSEN, P.A.M. \& VAN VUGHT, F.A. (Eds) (1989) Dutch Higher Education in Transition (Culemborg, Lemma).

MEEK, V.L. (1991) The transformation of Australian higher education from binary to unitary system, Higher Education, 21(4), pp. 461-495.

MiNiSTERIE VAN ONDERWIJS EN WETENSCHAPPEN (1991) Feiten en Cijfers (The Hague, SDU).

MosES, I. (1991) The binary experiment: success or wasted effort?, paper presented at the Special Conference on 25 Years After the Martin Report, University of New England, Armidale, Australia.

NeAve, G. (1983) The dynamics of integration in non-integrated systems of higher education in Western Europe, in: H. Hermanns, U. Teichler \& H. Wasser (Eds) The Compleat University (Cambridge, MA, Schenkman).

NeAve, G. (1990) On preparing for markets: trends in higher education in Western Europe, 1988-1990, European fournal of Education, 25(2), pp. 105-122.

NiJEBOER, J.J.B. (1990) Verschillen academici en HBO-ers in beloning en arbeidsmarktposities, Tijdschrift voor Hoger Onderwijs, 8(4), pp. 150-161.

OECD (1974) Short-cycle Higher Education: a search for identity (Paris, OECD).

RUITER, D.W.P. \& VAN VUGHT, F.A. (1990) Neo-functionalism in recent Dutch higher education legislation, European fournal of Education, 24(2), pp. 219-230.

SCHIPPERS, H. (1989) Van Tusschenlieden tot Ingenieurs: de geschiedenis von het Hoger Technisch Onderwijs in Nederland (Hilversum, Uitgeverij Verloren).

Silver, H. \& Brennan, J. (1988) A Liberal Vocationalism (London, Methuen).

Task Force on Human Resources, Education, Training and Youth (1991) Memorandum of the Commission on Higher Education in the European Community (Brussels, European Commission).

VossENSTEIJN, J.J. (1992) Stapelaars in het hoger onderwijs (Enschede, CHEPS, forthcoming).

WEERT, E. DE (1991) Higher education and employment: the case for the humanities and the social sciences in the Netherlands, in: P. M. M. vaN OIJEN (Ed.) Higher Education and Employment: the changing relationship (The Hague, SDU).

Zeijen, M.H.J. (1974) Perspectief van het Hoger Beroepsonderwijs (Tilburg, Katholieke Leergangen). 